\title{
Early life history and metamorphosis in Malo maxima Gershwin, 2005 (Carukiidae, Cubozoa, Cnidaria)
}

\author{
Avril H. Underwood ${ }^{1, *}$, Ilka Straehler-Pohl ${ }^{2}$, Teresa J. Carrette ${ }^{1}$, \\ JeSSiCA SLEEMAN $^{3} \&$ Jamie E. SEymour ${ }^{3}$ \\ ${ }^{1}$ College of Science and Engineering, Division of Tropical Environments and Societies, James Cook University, McGregor Road, \\ Smithfield, QLD 4878, Australia \\ ${ }^{2}$ Medusa Nursery, Private Laboratory for Life cycle, Developmental and Evolutionary Research, Altmarkstr. 25, 21684 Stade- \\ Hagen, Germany \\ ${ }^{3}$ Australian Institute of Tropical Health and Medicine, Centre for Biodiscovery and Molecular Development of Therapeutics, \\ College of Public Health, Medical \& Veterinary Sciences, Division of Tropical Health \& Medicine, James Cook University, \\ Smithfield, QLD 4878 Australia
}

Received 29 January 2018; Accepted 11 July 2018 Responsible Editor: Dhugal Lindsay

doi: $10.3800 /$ pbr. 13.143

\begin{abstract}
This research presents the early life history stages of Malo maxima, a recently described tropical Australian cubozoan from the family Carukiidae, from sexual fertilisation to metamorphosis including planula, polyp, asexual reproductive strategies and young medusa. We discuss the similarities between M. maxima and two closely related carukiid species from Japan and Australia including morphology and behaviours previously undocumented in the class Cubozoa. All three carukiids can reproduce by mono-disk strobilation, a strategy common to all other orders of the class Scyphozoa but only recently described in Cubozoa.
\end{abstract}

Key words: asexual reproduction, polyp, box jellyfish, Cubozoan life cycle, mono-disk strobilation

\section{Introduction}

Cubozoans (there is presently debate about this nomenclature with the suggestion that the order Cubomedusae is the correct classification as per Straehler-Pohl 2017) are cnidarians, some of which are capable of causing lifethreatening envenomations (Bengston et al. 1991, Suntrarachun et al. 2001, Carrette et al. 2012). Around 44-50 species of cubozoans have been described, however, the early life histories and asexual reproduction strategies of only a handful of species are known (Werner et al. 1971, Studebaker 1972, Werner 1973b, Werner 1975, Arneson \& Cutress 1976, Yamaguchi \& Hartwick 1980, Werner 1983, Hartwick 1991b, Carrette et al. 2014, Toshino et al. 2014a, Toshino et al. 2014b, Courtney et al. 2016, Toshino et al. 2017). For the majority of species whose polyps and early developmental stages have been observed, the descriptions are remarkably similar: planulae settle on hard substrate

* Corresponding author: Avril H. Underwood; E-mail, avril.underwood @my.jcu.edu.au and transform into a polypoid, sessile stage lacking inner anatomical structures (Werner et al. 1971, Studebaker 1972, Arneson \& Cutress 1976, Hartwick 1991b, Yamaguchi \& Hartwick 1980, Laska-Mehnert 1985, Nordström et al. 2003, Carrette et al. 2014, Toshino et al. 2014a, Toshino et al. 2014b, Straehler-Pohl 2017); planulae display pigment spots in a banding pattern (Werner et al. 1971, Studebaker 1972, Arneson \& Cutress 1976, Yamaguchi \& Hartwick 1980, Hartwick 1991b, Nordström et al. 2003, Carrette et al. 2014, Toshino et al. 2014a, Toshino et al. 2014b, Straehler-Pohl 2017); and polyps are capable of asexually producing secondary creeping polyps until undergoing complete metamorphosis into a free-swimming medusa with no regenerative polypoid residue remaining (Werner et al. 1971, Studebaker 1972, Werner 1973a, Werner 1973b, Werner 1975, Arneson \& Cutress 1976, Yamaguchi \& Hartwick 1980, Werner 1983, Laska-Mehnert 1985, Hartwick 1991b, Straehler-Pohl \& Jarms 2005, Straehler-Pohl 2009, Carrette et al. 2014, Toshino et al. 2014a, Toshino et al. 2014b, Straehler-Pohl 2017). These features of polyp anatomy and behaviour as well as medusa production by 
complete metamorphosis were considered unique to these species of jellyfish. This led Werner to elevate all known species with these shared characteristics to a new class, Cubozoa (Werner 1973a, Werner 1976), distinct from that of the class Scyphozoa within which they had previously been grouped.

Recent research has identified notable exceptions to these characteristics within order Carybdeida: polyps of Carybdea xaymacana Conant, 1897 (formerly Carybdea marsupialis from Puerto Rico-Studebaker 1972, Acevedo 2016) are capable of performing incomplete metamorphosis by leaving a regenerative residue behind from where new polyps are formed (Straehler-Pohl \& Jarms 2005); Alatina morandinii (Straehler-Pohl \& Jarms, 2011), formerly Carybdea morandinii Straehler-Pohl \& Jarms, 2011, displays inner structures in the polyps that divide the gastric cavity into compartments (Straehler-Pohl \& Jarms 2011); two species from the family Carukiidae, Morbakka virulenta (Kishinouye, 1910) and Carukia barnesi Southcott, 1967, produce planulae without eye spots, secondary polyps capable of swimming rather than creeping, and employ a form of mono-disk strobilation generally associated with the class Scyphozoa (Toshino et al. 2013, Toshino et al. 2015, Courtney et al. 2016).

In this paper we present the life cycle of Malo maxima Gershwin, 2005, a species within the family Carukiidae (order Carybdeida) located in tropical Australia. Our observations of the early life stages of M. maxima demonstrate similarities to the recently published life-histories of the two additional Carukiidae species (Toshino et al. 2013, Toshino et al. 2015, Courtney et al. 2016, Straehler-Pohl 2017) in addition to describing additional reproductive and morphologic characteristics also seen in scyphozoan life histories (Arai 1997, Straehler-Pohl 2017).

\section{Materials and Methods}

\section{Sampling of medusae}

Medusae of Malo maxima were collected on 14 April 2011 at Port Douglas Marina Queensland, Australia $\left(145^{\circ} 27^{\prime} 42^{\prime \prime} \mathrm{E}, 16^{\circ} 29^{\prime} 2^{\prime \prime} \mathrm{S}\right)$ on a slack tide approximately one hour after high tide (2.24 $\mathrm{m}$ at 18:27) between 19:20 and 20:00. Collection ended when no more M. maxima were found. Collection started approximately $80 \mathrm{~min}$ after sunset on a clear night with no wind. Malo maxima were located by suspending two $2 \times 1000$ Watt underwater lights in the water $20 \mathrm{~m}$ apart along the side of the main quay of the marina As specimens swam across the lit up area, they were scooped up using a flat pool net then transferred to individual plastic containers (size between $300-600 \mathrm{~mL}$ ) filled with fresh seawater. Animals were identified as carybdeids by their single tentacle extending from the pedalia, located at each of the four corners of the bell, but distinct from another carybdeid common to these waters, Carukia barnesi, as there were no distinctive 'tails' on the nematocyst bands of the tentacles (Southcott 1967). The specimens were later identified as M. maxima based on detailed observation of morphological characteristics by ISP (Straehler-Pohl 2014).

Within one hour of collection, 8 (5 males and 3 females) of the total 41 specimens collected spawned inside their containers (evident by the milky appearance of the water for males and eggs in the water for females). Artificial fertilisation of eggs and sperm was undertaken in situ at the sampling site. To do this, egg-laden water from a container holding a female specimen was transferred to a new container (between $200 \mathrm{~mL}$ and $600 \mathrm{~mL}$ ) using a $50 \mathrm{~mL}$ plastic syringe. Around 2 times more sperm-filled water from a container holding a male specimen was added to the new container to create a $2: 1$ sperm to egg ratio. The container was topped up with fresh filtered seawater. This process was repeated until all available containers had been filled. Containers were then transported back to James Cook University, Cairns.

\section{Cultivation of planulae}

Fertilised eggs and planulae were carefully pipetted from larger containers into multiple 24-well plates (volume per well: $2-3 \mathrm{~mL}$ ). Individual plates were cultured under three different conditions: 1) complete darkness at ambient temperature of $24-26^{\circ} \mathrm{C} ; 2$ ) in constant artificial light at ambient temperature of $24-26^{\circ} \mathrm{C}$; and 3) inside a constant temperature cabinet at approximately $28^{\circ} \mathrm{C}$ with a $12: 12$ $\mathrm{h}$ light : dark cycle. Wells were cleaned daily by pipetting seawater out of the wells and refilling them with fresh seawater (salinity 33-35).

\section{Cultivation of polyps and young medusae}

As no difference was seen in the development of primary polyps under the 3 different culturing conditions, all polyps and young medusae were subsequently housed in the JCU aquarium facility. They were maintained in fresh sea water of salinity between 33-35, at temperatures between $24-26^{\circ} \mathrm{C}$, and subject to the artificial lighting at the facility.

Primary polyps, which developed directly from planulae, were fed daily by flooding all wells with seawater containing rotifers. After $4 \mathrm{~h}$, superfluous rotifers were pipetted out of each well to avoid fouling and wells were refilled with fresh seawater. At the 4-5 tentacle stage, the polyp diet was enriched with 1st instar Artemia sp. nauplii and the feeding frequency was reduced to bi-weekly. At this stage of development, asexual reproduction of swimming polyps had begun (see 'Asexual reproduction') so $4 \mathrm{~h}$ after feeding, all excess water from the well plates was washed into one or other of two $30 \mathrm{~L}$ aerated $\mathrm{BiOrb}^{\mathrm{TM}}$ aquaria. This allowed the secondary polyps to colonise the larger tanks. The plates were refilled with fresh seawater (salinity 33-35) which was filtered through a Millipore $0.45 \mu \mathrm{L}$ Durapore ${ }^{\circledR}$ membrane.

After successful colonisation of the $\mathrm{BiOrb}^{\mathrm{TM}}$ aquaria, 
as determined by attachment and growth of polyps on the surface of each aquarium, all polyp plates were placed in the aquaria. These cultures were fed twice a week with newly hatched Artemia sp. nauplii. Salinity was monitored once a week and filtered freshwater added when necessary to maintain culture salinities between 33-35.

\section{Cultivation of newly detached medusae}

Detached swimming medusae were collected from the aquaria and placed in a $2.5 \mathrm{~L}$ rectangular glass tank with aeration via a silicon tube resting on the surface of the water. Airflow was kept low to reduce disturbance to medusae. Medusae were fed once daily on a diet of 1st instar Artemia $s p$. nauplii. Water was replaced daily with fresh filtered seawater (salinity 33-35) to avoid fouling.

\section{Measurements}

All measurements refer to a 12-tentacled polyp with relaxed stalk unless otherwise stated. Standard measurements of the polyps (Fig. 1) were defined as per StraehlerPohl et al. (2011): Calyx Length (CL)=length from gastric cavity base to tentacle crown rim; Mouth Disc Diameter $(\mathrm{MDD})=$ widest diameter of mouth disc; $\mathrm{StL}=$ the stalk length refers to maximal length of completely relaxed stalk from basal disc to gastric cavity base.

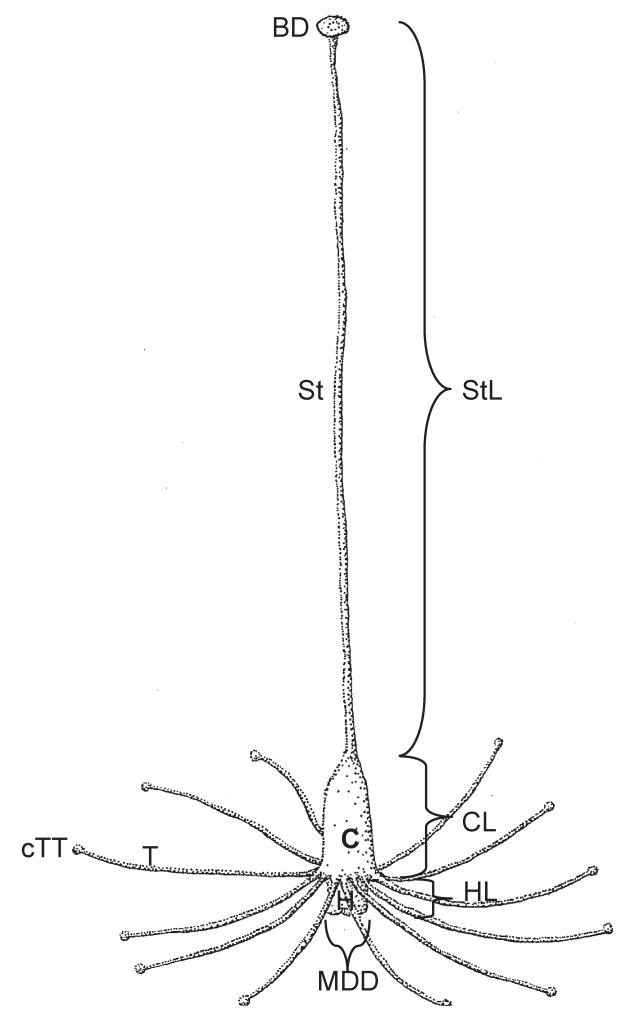

Fig. 1. Schematic drawing of anatomical characters and measurement of vertically suspended polyp of Malo maxima; BD: basal disc, C: calyx, CL: calyx length, cTT: capitate tentacle tip, H: hypostome, HL: hypostome length, MDD: mouth disc diameter, St: stalk, StL: stalk length, T: tentacle

\section{Identification of nematocysts}

To observe nematocysts for identification, tissue squashes from the tentacles and calices of 10 randomly selected polyps and two newly-detached medusa were observed using a ProSciTech OJXS304 triocular compound microscope under $400 \times$ magnification. Nematocysts were identified as per Östman (2000) and Gershwin (2006).

\section{Results}

\section{Primary polyp development}

Eggs were negatively buoyant and approximately $23 \mathrm{~h}$ after fertilisation, planulae were first observed rotating slowly within their membranes (Fig. 2a). The first planulae began to hatch shortly after (Fig. 2b, c). The hatched planulae showed no pigment spots (Fig. 2d) and moved freely in the well-plates at varying speeds. Planulae ceased hatching after approximately 7 days from the first hatching event. Planulae began attaching to the walls and the base of the wells approximately $24 \mathrm{~h}$ after hatching. Development of the planula into a primary polyp followed three distinct stages: 1) elongation from point of substrate attachment (within $24 \mathrm{~h}$ of settlement); 2) further elongation and definition of stalk, calyx with tentacle buds, extension of hypostome but not mouth opening (24 h after settlement); 3 ) stalk elongation, development of two tentacles, and mouth indentation on hypostome ( 2 days after settlement) (Fig. 2e). The tentacles contained eurytele nematocysts at their tip. Polyps bearing 4 or more tentacles began to reproduce asexually by lateral budding of secondary polyps approximately 12 days after planulae settlement (Fig. 2 g, Fig. $3 \mathrm{~g}-\mathrm{i})$. Approximately 24 days after settlement, polyps had developed up to 12 tentacles. Tentacles continued to be added as the polyp developed with a maximum of 23 tentacles observed on a single polyp.

\section{Description of fully developed polyp}

The polyp body was divided into three parts: the hypostome, the calyx, and a stalk region including a basal disc and a periderm collar enveloping the pedal region. The hypostome region included a single circlet of up to 23 capitate tentacles. The calyx was cup-shaped (MDD $0.31-0.37 \mathrm{~mm}, \mathrm{n}=5$; CL $1.6-2.0 \mathrm{~mm}, \mathrm{n}=5$ ) and the hypostome (HL 1.9-2 mm, n=5) was four-lipped and clubshaped (Fig. 3c). The whole polyp was white/translucent turning a distinct orange hue after feeding due presumably to the colouration of their diet, Artemia sp. nauplii. Brownish-green-coloured granules consistent with descriptions of zooxanthellae (Musatine 1974, Schlichter \& Fricke 1990, Arai 1997, Straehler-Pohl \&Jarms 2011) were observed in the tentacles and upper calyx of a small number of polyps. The knob-like tips of the tentacles contained up to 10 tightly-packed microbasic euryteles (Fig. 3d). These same nematocyst types were also found scattered in the ecto- 

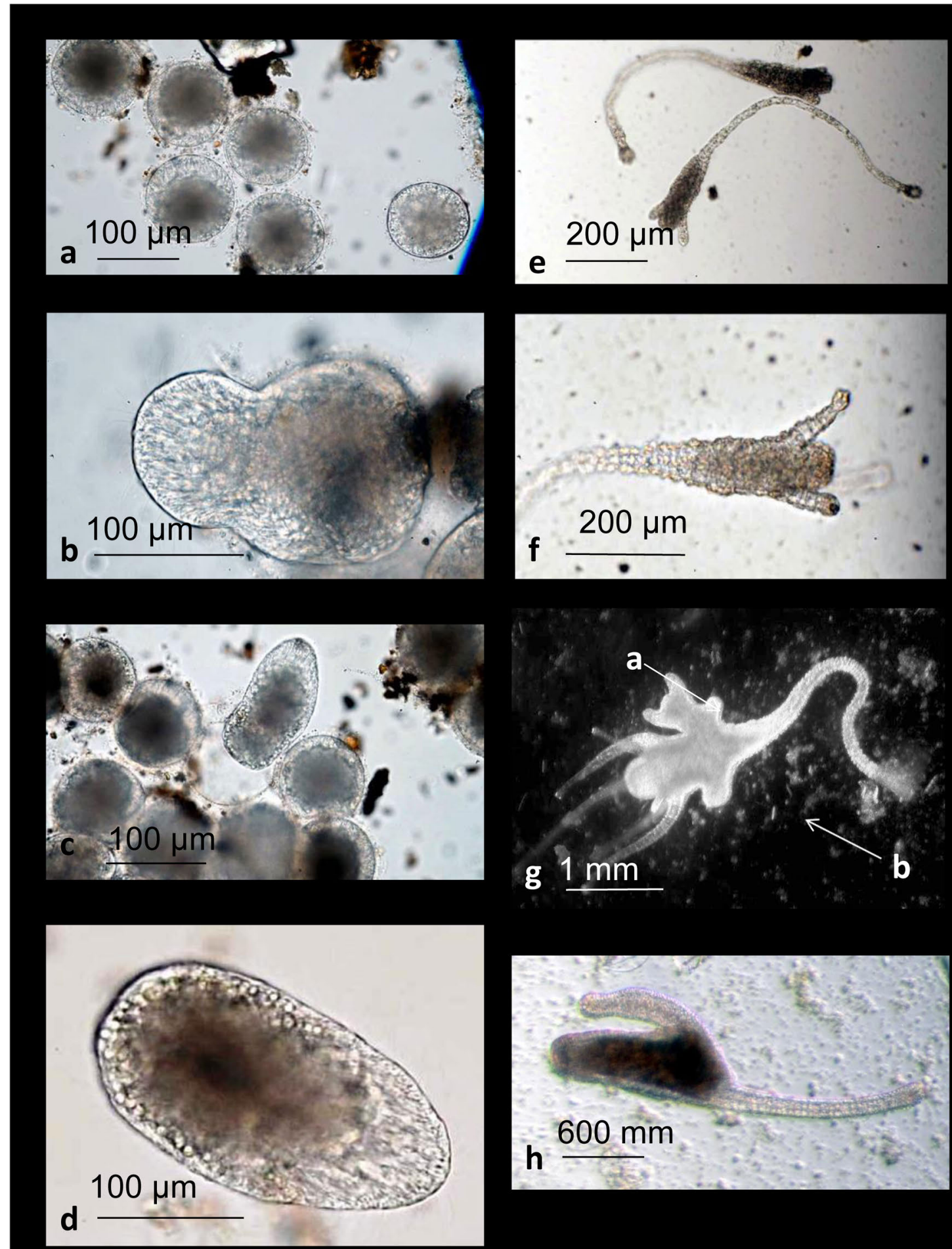

Fig. 2. Malo maxima early life stages. a, fertilised eggs; b, c, hatching planula; d, planula without eye spots; e, primary polyps; f, close up of the distal portion of primary polyp; g, polyp showing new asexual bud (a) and more developed asexual bud (b); h, detached swimming polyp bud.

derm of the calyx, which also contained a lesser number of smaller spherical isorhizae. The stalk had considerable contractile properties with muscle banding, the maximum extended length observed in any one polyp being approx- imately $50 \mathrm{~mm}$ (Fig. 1, Fig. 3a). Mechanical stimulation such as moving the tank, change in water flow or prey capture would induce stalk contraction. Fully contracted stalks of polyps on the base of a well would result in the 


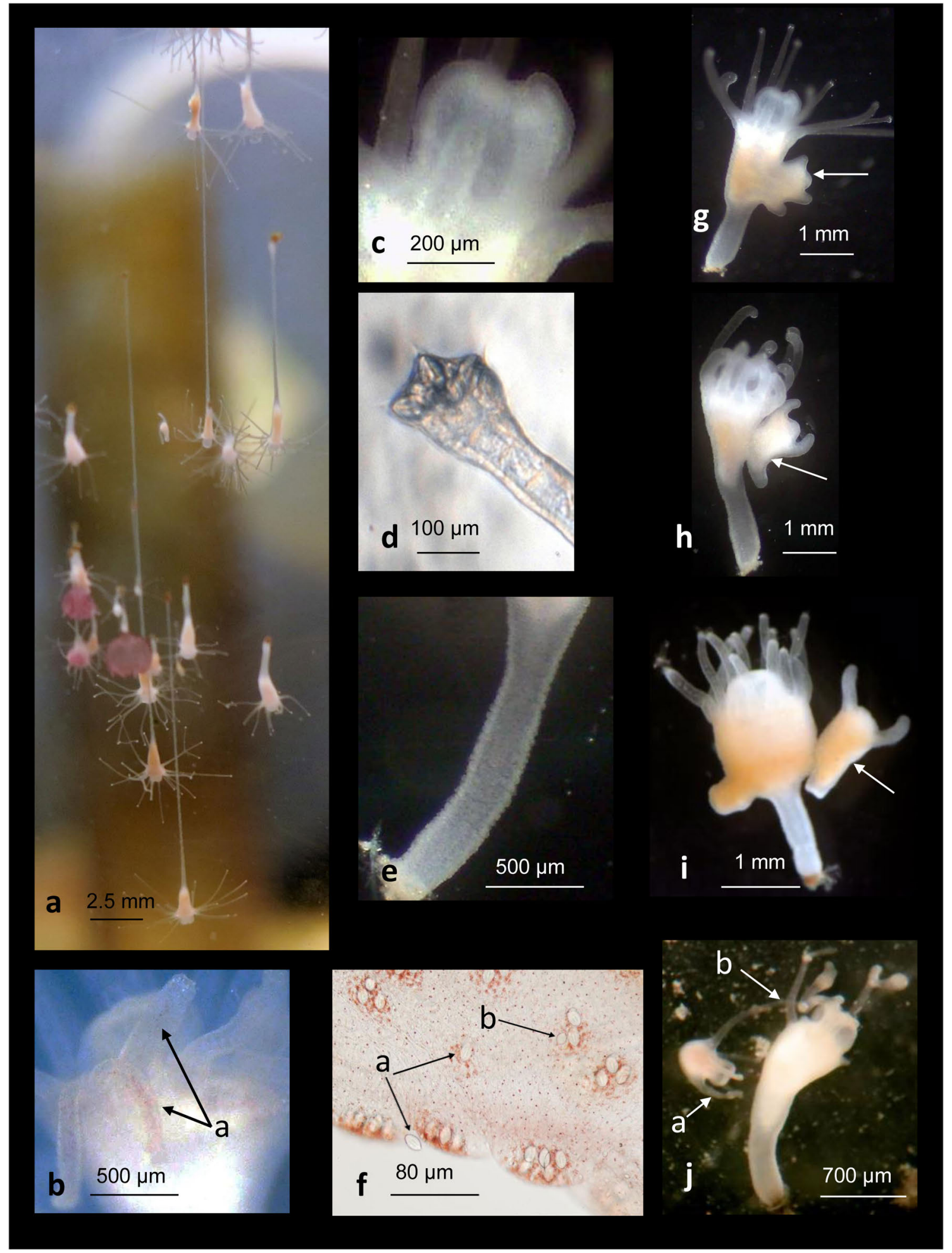

Fig. 3. Malo maxima polyp and asexual reproduction types. a, polyps and metamorphosis stages of Malo maxima attached to biOrb ${ }^{\mathrm{TM}}$ aquarium wall; b, coloured granular material consistent with zoozanthellae; c, large, four-lipped, club-shaped manubrium; d, tentacle tip of polyp with multiple microbasic euryteles; e, stalk showing rippled structure of epidermis due to contracted stage; f, raised warts on bell of newly metamorphosed medusa showing two types of nematocysts, (a) microbasic euryteles, (b) isorhizae; g-i, progression of budding of swimming polyp (arrow); j, polyp budding from tentacle tip, (a) points to secondary polyp calyx, (b) indicates connection point. 


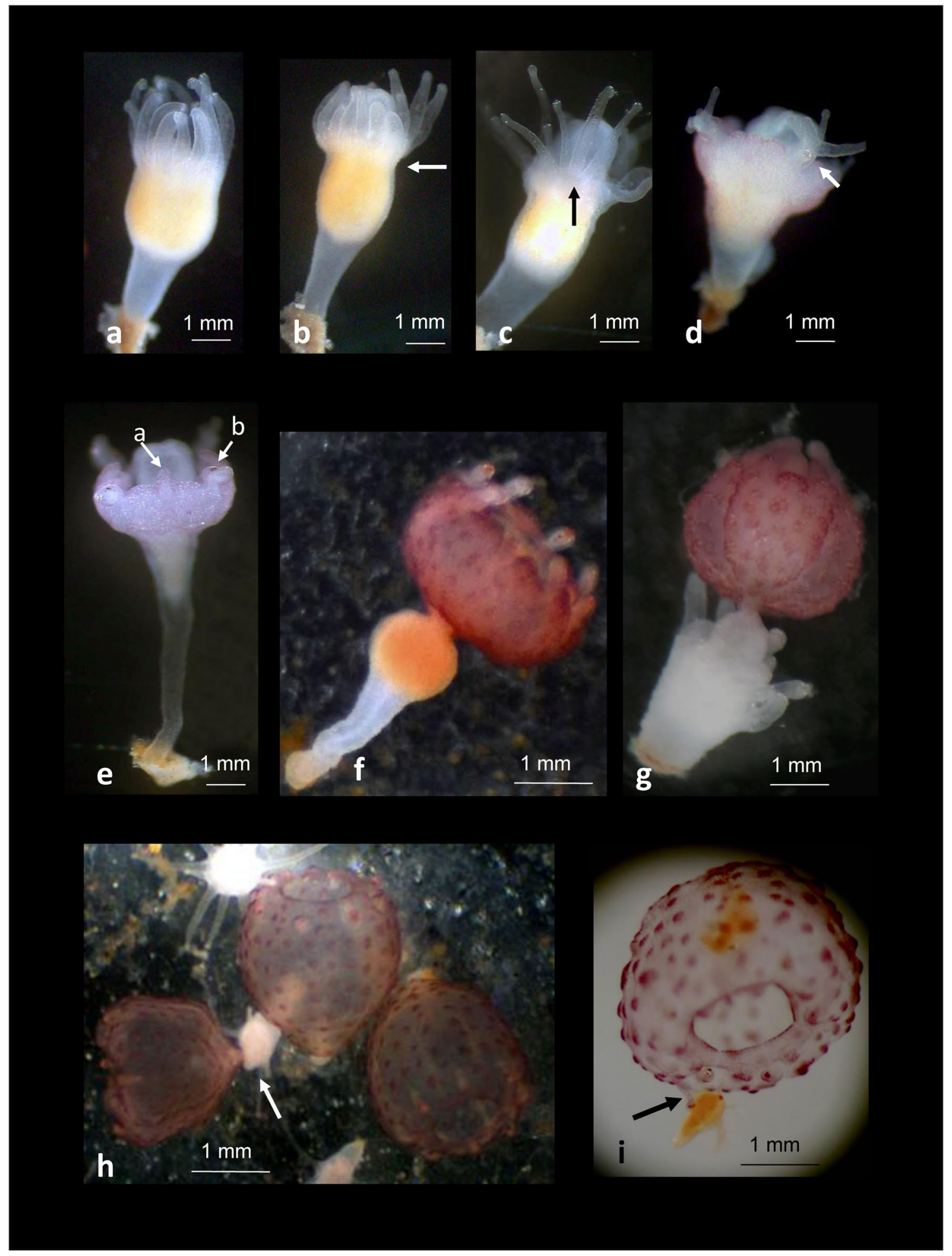

Fig. 4. Metamorphosis of Malo maxima. a, polyp before metamorphosis; b, first signs of metamorphosis, elongation of calyx, forming of horizontal groove (arrow), separating lower polypoid from transforming upper medusoid tissue; c, congregation of tentacle bases (arrow); d, fused tentacle bases forming rhopalia, tentacles being absorbed, note bowl-shape of upper calyx and forming statolith (arrow); e, tentacles completely absorbed, development of 2 major, median eyes and 4 minor, lateral eyes per rhopalium (b) and 1 medusoid tentacle per interradium (a); f, formation of a residuum beneath future apex of developing medusa; $\mathrm{g}$, h, polypoid features of calyx, hypostome and tentacles developing from residuum (arrow) prior to medusa detachment; i, newly detached medusa feeding on 1st instar Artemia sp. nauplius attached to tentacles (arrow). 
polyp sitting in an upright position.

\section{Asexual reproduction}

\section{Lateral budding of swimming polyps}

Asexual reproduction was first observed in polyps with 4 tentacles. The formation of buds was initially visible as a protrusion from the lower calyx region of the polyp, well below the mouth disc of the polyp. The protrusion transformed from knob-shaped to T-shaped with the appearance of two opposing tentacle buds at the tip of the initial protrusion. A second protrusion developed directly below the first one (Fig. 3g) resulting in a lateral connection to the parent polyp (Fig. 3h). The bud continued to grow out until there was minimal tissue connection to the parent polyp (Fig. 3i), upon rupturing the bud detached. The time from initial budding to detachment ranged between 2 to 6 days. Up to 4 buds were observed protruding simultaneously from a single polyp in varying stages of development.

Detached polyp buds were able to propel themselves vertically and horizontally through the water with the aid of beating cilia. They extended one tentacle in the direction of movement with the other positioned flat against the body (Fig. 2h). They were also found resting on the bottom of the wells or at the water surface. After a minimum of $24 \mathrm{~h}$, the detached buds settled on a substrate and attached by forming a basal disc enclosed by a peridermal cup. Within 4 days of attachment, the stalk elongated and additional tentacles began to form.

\section{Budding from tentacle tips}

Sessile polyps were occasionally observed with clubshaped swellings at their tentacle tips. These developed into miniature polyp calices with tentacles and a hypostome but no stalk (Fig. 3j). Detachment from the parent polyp was not observed. These tentacle buds were able to catch and ingest food while still attached.

\section{Longitudinal, intra-tentacular fission}

A small number of polyps were observed to undergo asexual propagation by longitudinal fission. This process began with centrifugal enlargement of the whole calyx, the hypostome, and the development of additional tentacles. The polyp then stretched into an ellipsoid form, and vertical furrows appeared on the lateral sides. The furrows deepened faster at the oral region than at the basal region. The hypostome then split into two parts. As the twin hypostomes moved further apart, the emerging twin polyp bodies were still connected at the calyx and basal disc. Fission was complete when the stalk tissue ruptured between the two polyps and the basal disc split into two. The resulting twin polyps were often different in size. Polyps were observed dividing in this way multiple times. Frequently, the first fission was not yet complete before a second started.

\section{Metamorphosis}

Metamorphosis of Malo maxima from a sessile polyp
(Fig. 4a) to a single, free-swimming medusa (Fig. 4i) was first observed 111 days after fertilisation. The first evidence of medusa development was the slight elongation of the calyx, a thickening of the mouth disc rim and the formation of a horizontal ring furrow below the tentacle crown (Fig. 4b) dividing the calyx into two sections: the upper metamorphosing and the lower polypoid part. The bases of the tentacles congregated in various numbers at 4 equidistant points around the hypostome, marking the perradii of the medusa (Fig. 4c). Above the horizontal ring furrow, the calyx showed a centrifugal size growth to form a bowl-shape (Fig. 4d). The tentacle bases fused and thickened into bulbs as their distal ends were absorbed. The outer part of the bulb began to form crystals of the future statolith (Fig. 4d). The polyp changed colour from pale orange to a lighter mauve in the transforming calyx. The upper part of the hypostome lost its radial symmetry and transformed into a square shape. Shortly before final absorption of the polyp tentacles, pigmented spots appeared on the inward facing side of the tentacle bulbs. These spots transformed into two median-located, lens-eyes and four lateral ocelli. After total transformation of the polyp tentacles into four cone-shaped rhopalia bearing the eyes and ocelli, four short tentacles arose equidistant between the rhopalia (Fig. 4e). The rhopalia changed from cone-shaped into a stemmed spherical form. With additional centrifugal growth, the calyx began to resemble the umbrella shape of a medusa bell. The bell turned from pale mauve to transparent pink with many large, reddish-pink coloured nematocyst clusters (containing microbasic euryteles and isorhizae) appearing on the exumbrella (Fig. 4f).

The horizontal ring furrow further constricted below the developing medusoid structure, resulting in a ball-shaped lower calyx of a regenerating residuum. This constriction created a tube (Fig. 4f) with tentacle buds forming around its edge. Detachment of the medusa (Fig. 4i) occurred after the residuum regenerated completely into a small polyp with up to 10 tentacles (Fig. 4g, h), with the entire metamorphosis lasting 3-7 days. After detachment, the remaining polyp fed and reproduced asexually. In a small number of cases, only the stalk, as regenerative remnant, remained while in others a complete metamorphosis with no residuum occurred.

\section{Description of newly detached medusae}

Newly detached medusae (Fig 4i) had a tetraradialsymmetric, spheroidally-pyramidal umbrella (niche-bell height: mean $=1.73 \mathrm{~mm}, \mathrm{SD}=2.01 \mathrm{~mm}$, inter-pedalial distance: mean $=1.75 \mathrm{~mm}, \mathrm{SD}=2.0 \mathrm{~mm}, \mathrm{n}=10$ ) and were pinkish in colour. Bell warts consisting of a predominately euryteles with a lesser number of spherical isorhizae (Fig. 3f) were regularly dispersed over the entire exumbrella. The manubrium was short (approx. 30\% of umbrella height), four-lipped and attached to a stomach, which contained no gastric filaments. Medusae had four thin, capitate tentacles, which when extended were the same length as the 
height of the umbrella. Medusae had four rhopalia with the rhopalial niche not yet developed.

\section{Feeding behaviour}

Medusae were observed feeding 2 days after metamorphosis. They caught 1st instar Artemia sp. nauplii on the ends of their tentacles (Fig. 4i) and retracted the tentacles towards the bell, extending the manubrium to pull the food into the gastrovascular cavity for digestion. Medusae were fed daily, however, no medusa observed for this study lived longer than one month. Deformation of bell, shrinkage, loss of colouration and reduced movement occurred before death.

\section{Discussion}

This description of the life history of both sessile and motile stages of the tropical Australian carybdeid Malo maxima is contrary to those of the majority of presently described Cubozoa, which include planula with pigmentation bands (Widersten 1968, Arneson \& Cutress 1976, Yamaguchi \& Hartwick 1980, Hartwick 1991a, Hartwick 1991b, Nordström et al. 2003, Carrette et al. 2014, Toshino et al. 2014a, Toshino et al. 2014b, Straehler-Pohl 2017), creeping polyps (Werner et al. 1971, Werner 1975, Arneson \& Cutress 1976, Yamaguchi \& Hartwick 1980, Werner 1983, Hartwick 1991a, Straehler-Pohl \& Jarms 2005, Adler \& Jarms 2009, Straehler-Pohl 2009, Straehler-Pohl \& Jarms 2011, Carrette et al. 2014, Kingsford \& Mooney 2014, Toshino et al. 2014a, Toshino et al. 2014b), and the complete metamorphosis of a single polyp into a single, fully-formed, free-living medusa with no remaining regenerative residuum (Werner et al. 1971, Studebaker 1972, Cutress \& Studebaker 1973, Werner 1973b, Arneson \& Cutress 1976, Werner 1976, Yamaguchi \& Hartwick 1980, Werner 1983, Laska-Mehnert 1985, Nordström et al. 2003, Straehler-Pohl \& Jarms 2005, Straehler-Pohl 2009, Straehler-Pohl \& Jarms 2011, Carrette et al. 2014, Kingsford \& Mooney 2014, Toshino et al. 2014a, Straehler-Pohl 2017).

\section{Planula}

The planula of Malo maxima did not possess pigmentation spots associated with cubozoans outside the family Carukiidae (Widersten 1968, Arneson \& Cutress 1976, Yamaguchi \& Hartwick 1980, Hartwick 1991b, Nordström et al. 2003, Carrette et al. 2014, Toshino et al. 2014a, Toshino et al. 2014b, Straehler-Pohl 2017). These spots are likely photoreceptors (Nordström et al. 2003) and their absence in carukiids suggests that either orientation to or away from light may not play a major role in dispersal and/or settlement and that there may be additional sensory structures within the planula that determine direction of movement and substrate choice (Sinigaglia et al. 2015).

Planula development differed between the three described carukiid species. In Malo maxima and Carukia barnesi, hatched planulae showed a swimming stage before settlement and development into a primary polyp, which is similar to other tropical cubozoans e.g. Carybdea xaymacana (Studebaker 1972), Alatina alata (Carrette et al. 2014, Lawley et al. 2016), Tripedalia cystophora (Werner 1975), Copula sivickisi (Toshino et al. 2014a) and Chironex fleckeri (Yamaguchi \& Hartwick 1980). The planula of Morbakka virulenta stayed inside its unhatched membrane until the development of the primary polyp was completed without a pelagic stage (Toshino et al. 2013). This reason for this difference is unclear, however it may be related to different dispersal and survival strategies undertaken by these species: $M$. virulenta uses the egg membrane as polyp substrate where no solid environmental substrate is present (Toshino et al. 2013) and the slow locomotion and negative buoyancy in $C$. barnesi is hypothesised to infer limited dispersal potential (Courtney et al. 2016).

\section{Polyp}

The main body structure of Malo maxima polyps is similar to that of all presently described cubopolyps (Werner et al. 1971, Studebaker 1972, Cutress \& Studebaker 1973, Werner 1973a, Arneson \& Cutress 1976, Yamaguchi \& Hartwick 1980, Straehler-Pohl 2009, Carrette et al. 2014, Courtney et al. 2016, Straehler-Pohl 2017, Straehler-Pohl \& Jarms 2011, Toshino et al. 2013, Toshino et al. 2014a, Toshino et al. 2014b, Toshino et al. 2017). Additionally, $M$. maxima displays certain features shared with a limited number of cubozoan species such as multiple nematocysts in the tentacle tips (Werner et al. 1971, Werner 1975, Chapman 1978, Toshino et al. 2013, Toshino et al. 2014a, Toshino et al. 2017) and an association with zooxanthellae (Straehler-Pohl \& Jarms 2011). Unique to M. maxima is the first observation of an extremely long stalk in a cubopolyp capable of expanding many times the length of the calyx. Certain scyphozoan species such as Cassiopea spp. (Gohar \& Eisawy 1960a), Mastigias papua Lesson, 1830 and Phyllorhiza punctata von Ledenfeld, 1884 (Straehler-Pohl 2009) display considerable ability to lengthen their stalks (Straehler-Pohl 2017) supported by surrounding peridermal tubes, which allow an upward extension of the calyx. No supporting peridermal tube was observed in polyps of $M$. maxima, with polyps attached to the side of aquaria capable of extreme downwards movement but restricted upward extension. A preference for attachment to vertical surfaces and undersides of substrates has been observed in a number of cnidarian species (Brewer 1976, Grondahl 1989, Hartwick 1991a, Holst \& Jarms 2006, Holst 2008) allowing prey capture from the water column. The extended stalk of M. maxima may enable the tentacles to be further reaching with greater flexibility in the surrounding current.

\section{Asexual reproduction}

Lateral budding in Malo maxima started at the 4-tentacle stage and followed a similar developmental path to 
that described for Morbakka virulenta (Toshino et al. 2013) and Carukia barnesi (Courtney et al. 2016). The resulting secondary polyps are thus far unique to the family Carukiidae in their capacity to swim by beating cilia to propel themselves through the water column while extending one of their two tentacle tips in the direction of movement. An advantage of this method of swimming compared to the creeping observed in secondary polyps of other cubozoan families (Werner et al. 1971, Arneson \& Cutress 1976, Yamaguchi \& Hartwick 1980, Straehler-Pohl \& Jarms 2005, Carrette et al. 2014, Toshino et al. 2014a, Toshino et al. 2014b) may be that while the latter require a substrate on which to creep, the swimming carukiid polyps can move freely in the water column (Toshino et al. 2013, Courtney et al. 2016).

A second type of asexual reproduction seen in Malo maxima, longitudinal fission, has previously been noted in all classes of cnidarians (Minasian Jr 1976, Pitt 2000, Geller et al. 2005, Adler \& Jarms 2009, Morandini et al. 2009) including a single cubozoan, Carybdea morandinii (Straehler-Pohl \& Jarms 2011). This mode of asexual reproduction facilitates rapid development of fully formed polyps that can immediately feed and begin lateral budding or metamorphosis/strobilation (Straehler-Pohl \& Jarms 2011). Tentacle tip budding observed in a small proportion of M. maxima polyps is also found in Sanderia malayensis Goette, 1886, a peculiar scyphozoan species that displays multiple methods of asexual reproduction (Adler \& Jarms 2009).

\section{Metamorphosis}

Medusa production in the family Carukiidae displays characteristics previously not observed in cubozoans. The centrifugal growth of the calyx into a bowl shape had previously been restricted to scyphozoan species, e.g., Sanderia malayensis (Adler \& Jarms 2009), Cassiopea xamachana Bigelow, 1892 (Bigelow 1900), Cassiopea andromeda Escholtz, 1829 (Gohar \& Eisawy 1960a, Gohar \& Eisawy 1960b, Straehler-Pohl 2009), Cephea cephea, Forskål, 1775 (Uchida 1929, Straehler-Pohl 2009) and Mastigias papua (Sugiura 1966, Straehler-Pohl 2009). Carukiidae is also the only cubozoan family that has been documented regenerating a fully functioning polyp prior to medusa detachment (Toshino et al. 2015, Courtney et al. 2016) analogous to mono-disc strobilation, as well as whole polyp metamorphosis. Although a number of polyps of Malo maxima did undergo complete metamorphosis with no remaining residuum, a greater proportion was able to regenerate a fully functioning polyp prior to medusa detachment. Strobilation as an asexual reproductive strategy is a common characteristic of scyphozoan life cycles (Chuin 1930, Arai 1997, Fuentes et al. 2011, Schiariti et al. 2008, StraehlerPohl 2009, Straehler-Pohl 2017). Monodisc strobilation is particularly prevalent in rhizostome species within the order Cepheida (Bigelow 1900, Sugiura 1965, Sugiura 1966, Hofmann et al. 1978, Straehler-Pohl 2009, Straehler-Pohl
2017) and a lesser number of species in other scyphozoan groups such as the Pelagiidae (Uchida \& Sugiura 1978, Adler \& Jarms 2009) and Cyaneidae (Dong et al. 2006, Dong et al. 2008). Prior to these studies on the family Carukiidae, all published life cycles within order Cubozoa had described a complete metamorphosis of a polyp into a single medusa (Werner et al. 1971, Studebaker 1972, Cutress \& Studebaker 1973, Werner 1973a, Werner 1975, Arneson \& Cutress 1976, Yamaguchi \& Hartwick 1980, Werner 1983, Laska-Mehnert 1985, Stangl et al. 2002, Straehler-Pohl \& Jarms 2005, Straehler-Pohl \& Jarms 2011, Carrette et al. 2014).

\section{Developmental degree of newly detached medusa}

Newly detached medusae of Malo maxima were similar in morphological structure to other cubozoan species (Cutress \& Studebaker 1973, Straehler-Pohl \& Jarms 2011) with the exception of no observable gastric filaments. This trait is common to the two closely related carukkid species, Morbakka virulenta and Carukia barnesi, which never display gastric filaments at any point of development.

In this study we have shown that Malo maxima shares characteristics common to other species of the class Cubozoa: a lack of pigment spots on the planula, the production of a swimming secondary polyp and no gastric filaments in the newly detached medusa (Toshino et al. 2015, Courtney et al. 2016). Additionally, M. maxima shows asexual reproductive strategies of longitudinal fission, secondary polyp development from tentacles and a form of mono-disk strobilation, all of which are more commonly observed in scyphozoan orders (Delap 1907, Kakinuma 1967, Yasuda 1979, Widmer 2006, Holst 2008, Adler \& Jarms 2009, Straehler-Pohl \& Jarms 2011) and other classes of cnidarians (Fautin 2002).

\section{Acknowledgements}

We would like to thank Sandy Taylor for her technical and practical assistance with both the rearing and observations of Malo maxima for this paper and to Prof. André C. Morandini for kindly reviewing an early version of the manuscript. We are indebted to Reef One for donating $\mathrm{BiOrb}^{\mathrm{TM}}$ for the polyp cultures, to Port Douglas Marina for the generous use of their facilities, and the Australian Lions Foundation for ongoing financial support for cubozoan research. Thanks also go to Dr David Bloom for manuscript editing. Finally, thank you to Alicia Knudsen and Andy Cowan of Port Douglas for bringing the presence of large numbers of these spawning animals to our attention.

\section{References}

Acevedo M (2016) Biology, ecology and ecophysiology of the box jellyfish Carybdea marsupialis (Cnidaria: Cubozoa). $\mathrm{PhD}$ thesis. Universitat Politècnica de Catalunya, Mayaguez, 138 pp. 
Adler L, Jarms G (2009) New insights into reproductive traits of scyphozoans: special methods of propagation in Sanderia malayensis GOETTE, 1886 (Pelagiidae, Semaeostomeae) enable establishing a new classification of asexual reproduction in the class Scyphozoa. Mar Biol 156 (7): 1411-1420.

Arai MN (1997) A Functional Biology of Scyphozoa. Chapman \& Hall, London, 316 pp.

Arneson A, Cutress C (1976) Life history or Carybdea alata Reynaud, 1830 (Cubozoa). In: Coelenterate Ecology and Behaviour (ed Mackie G). Plenum Press, New York, pp. 227-236.

Bengston K, Nichols M, Schnadig V, Ellis MD (1991) Sudden death in a child following jellyfish envenomation by Chiropsalmus quadrumanus: case report and autopsy findings. JAMA 266 (10): 1404-1406.

Bigelow R (1900) The anatomy and development of Cassiopeia xamachana. Mem Boston Soc Nat Hist 5: 191-236.

Brewer R (1976) Larval settling behavior in Cyanea capillata (Cnidaria: Scyphozoa). Biol Bull 150 (2): 183-199.

Carrette T, Straehler-Pohl I, Seymour J (2014) Early life history of Alatina cf. moseri populations from Australia and Hawaii with implications for taxonomy (Cubozoa: Carybdeida, Alatinidae). PloS ONE 9 (1): e84377.

Carrette T, Underwood A, Seymour J (2012) Irukandji syndrome: a widely misunderstood and poorly researched tropical marine envenoming. Diving Hyperb Med 42: 214-223.

Chapman D (1978) Microanatomy of the cubopolyp, Tripedalia cystophora (Class Cubozoa). Helgolander Wiss Meer 31 (1-2): 128-168.

Chuin T (1930) Le cycle evolutif du scyphistome de Chrysaora. Trav Stat Biol Roscoff 8: 1-179.

Courtney R, Browning S, Seymour J (2016) Early life history of the irukandji jellyfish Carukia barnesi. PLoS ONE 11 (3): $1-13$.

Cutress C, Studebaker J (1973) Development of the Cubomedusae Carybdea marsupialis. Proc Ass Is Mar Lab Caribb 9 (1): 25.

Delap M (1907) Notes on the rearing, in an aquarium, of Aurelia aurita, L. and Pelagia perla (Slabber). Rep Sea and Fish Ire 1905, Part II Sci Invest: 160-164.

Dong J, Liu C, Wang Y, Wang B (2006) Laboratory observations on the life cycle of Cyanea nozakii (Semeostomida, Scyphozoa). Acta Zool Sinica 52 (2): 389-395.

Dong J, Sun M, Wang B, Liu H (2008) Comparison of life cycles and morphology of Cyanea nozakii and other scyphozoans. Plankton Benthos Res 3 (Supplement): 118-124.

Fautin DG (2002) Reproduction of cnidaria. Can J Zool 80 (10): $1735-1754$.

Fuentes V, Straehler-Pohl I, Atienza D, Franco I, Tilves U, Gentile M, Acevedo M, Olariaga A, Gili J-M (2011) Life cycle of the jellyfish Rhizostoma pulmo (Scyphozoa: Rhizostomeae) and its distribution, seasonality and inter-annual variability along the Catalan coast and the Mar Menor (Spain, NW Mediterranean). Mar Biol 158 (10): 2247-2266.

Geller JB, Fitzgerald LJ, King CE (2005) Fission in sea anemones: integrative studies of life cycle evolution. Integr Comp Biol 45 (4): 615-622.

Gershwin L (2006) Nematocysts of the Cubozoa. Zootaxa 1232: $1-57$.
Gohar H, Eisawy A (1960a) The biology of Cassiopea andromeda (from the Red Sea) (With a note on the species problem). Publ Mar Biol Sta Ghardaqa 11: 3-39.

Gohar H, Eisawy A (1960b) The development of Cassiopea andromeda (Scyphomedusae). Publ Mar Biol Sta Ghardaqa 11: 148-190.

Grondahl F (1989) Evidence of gregarious settlement of planula larvae of the scyphozoan Aurelia aurita: an experimental study. Mar Ecol Prog Ser 56: 119-125.

Hartwick R (1991a) Distributional ecology and behaviour of the early life stages of the box-jellyfish Chironex fleckeri. Hydrobiologia 216 (1): 181-188.

Hartwick R (1991b). Observations on the anatomy, behaviour, reproduction and life cycle of the cubozoan Carybdea sivickisi. Hydrobiologia 216 (1): 171-179.

Hofmann D, Neumann R, Henne K (1978) Strobilation, budding and initiation of scyphistoma morphogenesis in the rhizostome Cassiopea andromeda (Cnidaria: Scyphozoa). Mar Biol 47 (2): 161-176.

Holst S (2008) Grundlaegen der Populationsentwicklung verschiedener Schyphozoa (Cnidaria) der Deutschen Bucht. PhD thesis. Universität Hamburg, Hamburg (in German), 154 pp.

Holst S, Jarms G (2006) Substrate choice and settlement preferences of planula larvae of five Schyphozoa (Cnidaria) from the German Bight, North Sea. Mar Biol 151: 863-871.

Kakinuma Y (1967) Development of a scyphozoan, Dactylometra pacifica Goette. Bull Mar Biol Sta Asamushi 13 (1): 29-34.

Kingsford MJ, Mooney CJ (2014) The ecology of box jellyfishes (Cubozoa). In: Jellyfish Blooms (eds Pitt KA, Lucas CH). Springer Publishers, Netherlands, pp. 267-302.

Laska-Mehnert G (1985) Cytologische Veränderungen während der Metamorphose des Cubopolypen Tripedalia cystophora (Cubozoa, Carybdeidae) in die Meduse. Helgolander Meeresun 39 (2): 129-164.

Lawley JW, Ames CL, Bentlage B, Yanagihara A, Goodwill R, Kayal E, Hurwitz K, Collins AG (2016) Box jellyfish Alatina alata has a circumtropical distribution. Biol Bull 231 (2): 152-169.

Minasian Jr L (1976) Characteristics of asexual reproduction in the sea anemone Haliplanella luciae (Verrill), reared in the laboratory. In: Coelenterate Ecology and Behaviour (ed Mackie G). Plenum Press, New York, pp. 289-298.

Morandini AC, Stampar SN, Migotto AE, Marques AC (2009) Hydrocoryne iemanja (Cnidaria), a new species of Hydrozoa with unusual mode of asexual reproduction. J Mar Biol Assoc UK 89 (1): 67-76.

Musatine L (1974) Endosymbiosis of cnidarians and algae. In: Coelenterate Biology: Reviews and New Perspectives (eds Lenhoff HM, Muscatine L). New York: Academic Press, New York, pp. 539-593.

Nordström K, Seymour J, Nilsson D (2003) A simple visual system without neurons in jellyfish larvae. Proc R Soc Lond B Biol Sci 270 (1531): 2349-2354.

Östman C (2000) A guideline to nematocyst nomenclature and classification, and some notes on the systematic value of nematocysts. Sci Mar 64 (S1): 31-46.

Pitt K (2000) Life history and settlement preferences of the edible jellyfish Catostylus mosaicus (Scyphozoa: Rhizostomeae). 
Mar Biol 136 (2): 269-279.

Schiariti A, Kawahara M, Uye S, MianzanHW (2008) Life cycle of the jellyfish Lychnorhiza lucerna (Scyphozoa: Rhizostomeae). Mar Biol 156: 1-12.

Schlichter D, Fricke H (1990) Coral host improves photosynthesis of endosymbiotic algae. Naturwissenschaften 77: 447-450.

Sinigaglia C, Busengdal H, Lerner A, Oliveri P, Rentzsch F (2015) Molecular characterization of the apical organ of the anthozoan Nematostella vectensis. Dev Biol 398 (1): 120-133.

Southcott R (1967) Revision of some Carybdeidae (Scyphozoa: Cubomedusae), including a description of the jellyfish responsible for the "Irukandji Syndrome." Aust J Zool 15: 651-671.

Stangl K, Salvini-Plawen L, Holstein T (2002) Staging and induction of medusa metamorphosis in Carybdea marsupialis (Cnidaria, Cubozoa). Vie et milieu 52 (4): 131-140.

Straehler-Pohl I (2009) Die Phylogenie der Rhopaliophora (Scyphozoa und Cubozoa) und die Paraphylie der 'Rhizostomeae'. $\mathrm{PhD}$ thesis. Universität Hamburg, Hamburg, 374 pp.

Straehler-Pohl I (2014) Critical evaluation of characters for species identification in the cubomedusa genus Malo (Cnidaria, Cubozoa, Carybdeida, Carukiidae). Plankton Benthos Res 9 (2): 83-98.

Straehler-Pohl I (2017). Cubozoa and Scyphozoa: The results of 20 years of scyphozoan life cycle research with new results on cubozoan life cycles to suggest a new nomenclature referring to both classes. In: Frontiers in Ecological Studies of Jellyfish (eds Toyokawa M, Miyake H, Nishikawa J). Seibutsu Kenkyu Sha Co. Ltd., Tokyo, pp. 17-29.

Straehler-Pohl I, Jarms G (2005) Life cycle of Carybdea marsupialis Linnaeus, 1758 (Cubozoa, Carybdeidae) reveals metamorphosis to be a modified strobilation. Mar Biol 147 (6): 1271-1277.

Straehler-Pohl I, Jarms G (2011) Morphology and life cycle of Carybdea morandinii, sp. nov. (Cnidaria), a cubozoan with zooxanthellae and peculiar polyp anatomy. Zootaxa 2755: 36-56.

Straehler-Pohl I, Toshino S (2015) Carybdea morandinii-New investigations on its life cycle reveal its true genus: Carybdea morandinii Straehler-Pohl \& Jarms, 2011 becomes Alatina morandinii (Straehler-Pohl \& Jarms, 2011). Plankton Benthos Res 10 (4): 167-177.

Straehler-Pohl I, Widmer CL, Morandini AC (2011) Characterizations of juvenile stages of some semaeostome Scyphozoa (Cnidaria), with recognition of a new family (Phacellophoridae). Zootaxa 2741 (1): 1-37.

Studebaker J (1972) Development of the Cubomedusae, Carybdea marsupialis. Masters thesis. University of Puerto Rico, Mayaguez, $86 \mathrm{pp}$.

Sugiura Y (1965) On the life history of rhizostome medusae III. On the effects of temperature on the strobilation of Mastigius papua. Biol Bull 128: 493-496.

Sugiura Y (1966) On the life history of rhizostome medusae IV. Cephea cephea. Embryologia 9: 105-122.

Suntrarachun S, Roselieb M, Wilde H, Sitprija V (2001) A fatal jellyfish encounter in the Gulf of Siam. J Travel Med 8 (3): 150-151.

Toshino S, Miyake H, Iwanaga S (2014a) Development of Copula sivickisi (Stiasny, 1926) (Cnidaria: Cubozoa: Carybdeidae: Tripedaliidae) collected from the Ryukyu Archipelago, south- ern Japan. Plankton Benthos Res 9 (1): 32-41.

Toshino S, Shibata H, Miyake H (2014b) Development of $\mathrm{Ca}$ rybdea brevipedalia (Kishinouye, 1891) (Cnidaria: Cubozoa: Carybdeida: Carybdeidae) collected from northern Japan. International Council for the Exploration of the Sea. ICES CM 2014/3934 A: 40

Toshino S, Miyake H, Ohtsuka S, Adachi A, Kondo Y, Okada S, Hirabayashi T, Hiratsuka T (2015) Monodisc strobilation in japanese giant box jellyfish Morbakka virulenta (Kishinouye, 1910): a strong implication of phylogenetic similarity between Cubozoa and Scyphozoa. Evol Dev 17 (4): 231-239.

Toshino S, Miyake H, Ohtsuka S, Okuizumi K, Adachi A, Hamatsu Y, Urata M, Nakaguchi K, Yamaguchi S (2013) Development and polyp formation of the giant box jellyfish Morbakka virulenta (Kishinouye, 1910) (Cnidaria: Cubozoa) collected from the Seto Inland Sea, western Japan. Plankton Benthos Res 8 (1): 1-8.

Toshino S, Miyake H, Srinui K, Luangoon N, Muthuwan V, Sawatpeera S, Honda S, Shibata H (2017) Development of Tripedalia binata Moore, 1988 (Cubozoa: Carybdeida: Tripedaliidae) collected from the eastern Gulf of Thailand with implications for the phylogeny of the Cubozoa. Hydrobiologia 792 (1): 37-51.

Uchida T (1929) Studies on the Stauromedusae and Cubomedusae, with special reference to their metamorphosis. Jpn J Zool 2 (2): 103-193.

Uchida T, Sugiura Y (1978) On the polyp of the scyphomedusa, Sanderia malayensis and its reproduction. J Fac Sci Hokkaido Imp Univ, Ser 5, Zoology JOU 21 (2): 279-286.

Werner B (1973a) New investigations on systematics and evolution of the class Scyphozoa and the phylum Cnidaria. Publ Seto Mar Biol Lab 20: 35-61.

Werner B (1973b) Spermatozeugmen und Paarungsverhalten bei Tripedalia cystophora (Cubomedusae). Mar Biol 18: 212-217.

Werner B (1975) Bau und Lebensgeschichte des Polypen von Tripedalia cystophora (Cubozoa, class. nov., Carybdeidae) und seine Bedeutung für die Evolution der Cnidaria. Helgoland Wiss Meer 27 (4): 461-504.

Werner B (1976) Die neue Cnidarierklasse Cubozoa. Verh Dtsch Zool Ges: 230.

Werner B (1983) Die Metamorphose des Polypen von Tripedalia cystophora (Cubozoa, Carybdeidae) in die Meduse. Helgolander Meeresun 36 (3): 257-276.

Werner B, Cutress C, Studebaker J (1971) Life cycle of Tripedalia cystophora Conant (Cubomedusae). Nature 232: 582-583.

Widersten B (1968) On the morphology and development in some cnidarian larvae. Zool Bidr Upps 37: 139-182.

Widmer CL (2006) Life cycle of Phacellophora camtschatica (Cnidaria: Scyphozoa). Invertebr Biol 125 (2): 83-90.

Yamaguchi M, Hartwick R (1980) Early life history of the sea wasp, Chironex fleckeri (Class Cubozoa). Development and Cellular Biology of Coelenterates (eds Tardent P \& Tardent R): North-Holland Biomedical Press, Amsterdam, pp 11-16.

Yasuda T (1979) Studies on reproductive biology of harmful marine animals-The common jelly-fish, Aurelia aurita, along coast of Wakasa Bay, Japan Sea. In: Procedings of the $7^{\text {th }}$ Japan-Soviet Symposium Aquaculture (ed Yamamoto G). Tokai University Press, Tokyo, pp 185-195. 